\title{
Water-cover influences on diatom ingestion rates by meiobenthic copepods
}

\author{
Alan W. Decho \\ Department of Zoology and Physiology, Louisiana State University, Baton Rouge, Louisiana 70803, USA
}

\begin{abstract}
Laboratory experiments on meiobenthic copepods using ${ }^{14} \mathrm{C}$-diatoms were conducted to investigate whether: (1) feeding rates or (2) food sources (planktonically-suspended foods or benthic sediment-associated foods) vary in response to the presence or absence of water-cover (i.e. simulated High-water vs Low-water conditions). Three diatom-feeding harpacticoids were examined. Scottolana canadensis feeds at significantly higher rates $(2 \times)$ during High-water $(\mathrm{HW})$ conditions $(\mathrm{P}<0.001)$, at which time it consumes planktonic foods; during Low-water (LW), feeding is greatly reduced. These feeding patterns are related to its burrow-dwelling and to its subtidal habitat. Cletocamptus deitersi remains virtually unaffected by changes in ambient water-cover, feeding at nearly equal rates during HW and LW conditions but always tending to consume more benthic diatoms. Microarthridion littorale consumes food at nearly equal rates during $\mathrm{HW}$ and LW conditions, but does so by shifting its feeding mode. During HW-times it makes excursions into the water column, feeding on planktonicallysuspended foods. During LW-times it feeds benthically, moving over the sediment surface. Such feeding differences must affect meso-scale distributions of meiobenthos in the field, total benthic consumption and energy-flow estimates over a tidal-cycle, and the coupling of benthic and pelagic systems.
\end{abstract}

\section{INTRODUCTION}

Meiobenthic animals living at or near the intertidal limits of a salt marsh are exposed to a variety of physical conditions and potential food resources imposed by the fluctuating tidal cycle. During highwater conditions, the presence of water-cover over the sediment brings an influx of planktonic food resources (planktonic diatoms, detritus, heterotrophic bacteria) to the bottom and may permit meiofauna to enter the water column to better exploit these resources. Hydrodynamic effects on distribution (Eckman 1983, Jumars \& Nowell 1984 ) and predation pressure by small fish (Bodiou \& Villiers 1978) and invertebrates might be most intense on the meiobenthos during this stage (Fleeger 1980). At high-water, micro-algal grazers can potentially feed on (1) suspended planktonic food, (2) benthic (sedimentassociated) food, or (3) both.

During low-water conditions, however, mudflat exposure may potentially limit feeding of some species. Much of the planktonically-suspended material has been removed in the outflow, some may now rest on the sediment surface. While predation can still be significant (Bell 1980), hydrodynamic effects are virtually non-existent due to lack of water cover. Grazing by meiobenthos, therefore, is limited to benthic (sediment) associated sources.

One might conclude that saltmarsh meiofauna, owing to their sediment-associated nature, feed at relatively constant rates over a tidal cycle. Recent studies, however, have shown that behavioral patterns affect both activity and movement (passive or active) of meiofauna over a tidal cycle, in a highly speciesspecific fashion (Fleeger et al. 1984, Palmer 1984). It therefore follows that these changes in activities or movements (with regard to tidal-level), may also influence both feeding rates and the type of food ingested (planktonic or benthic) at different parts of a tidal cycle.

The purpose of this study was to examine 2 aspects of meiobenthic harpacticoid copepods feeding on diatoms. First, to determine how the ingestion rate of diatoms by harpacticoids varies over simulated parts of a tidal cycle (presence or absence of water-cover; High-water vs Low-water conditions); second, to determine if these harpacticoids feed on (1) benthicallyderived foods, or (2) planktonically-derived foods, or (3) both. 


\section{METHODS}

Copepod collection. Harpacticoid copepod species used in feeding experiments were collected from an intertidal mudflat in a Spartina alterniflora marsh near Cocodrie, Louisiana (USA), and maintained in laboratory sediment culture chambers (Chandler 1986) until use. Three harpacticoids were used: Scottolana canadensis, Cletocamptus deitersi, Microarthridion littorale. These 3 harpacticoids are known diatom feeders (Decho unpubl.) traditionally considered infaunal or epibenthic. However, they differ considerably in their movements and apparent feeding activities during High-water (HW) and Low-water (LW) conditions (Chandler unpubl.). S. canadensis has been considered epibenthic, but is now known to be a semi-sessile burrow-dweller which may leave its burrow to swim; $C$. deitersi is a benthic harpacticoid which appears equally facile at infaunal and surface movement during HW and LW conditions; $M$. littorale is epibenthic (Palmer 1984).

Diatom culture. Two diatom species were used as food in feeding experiments. A planktonic species, Thalassiosira weissflogii, commonly found in salt marsh phytoplankton, was obtained from the Texas Algal Collection and grown in $\mathrm{f}-2$ media (Guillard \& Ryther 1962) in $15 \%$ Instant Ocean Artificial Seawater (ASW) using $16 \mathrm{~h}$ light $8 \mathrm{~h}$ dark cycle at $20^{\circ} \mathrm{C}$. The benthic (sediment) diatom Amphora tenerrima (Aleem \& Hustedt) was isolated from salt marsh sediments and grown on Erdschreibers media under similar conditions. Cultures were kept under near-axenic conditions using Penicillin (10000 $\mathrm{U} \mathrm{ml}^{-1}$ final conc.) and Vancomycin $\left(0.2 \mathrm{mg} \mathrm{ml}^{-1}\right.$ final conc.). These 2 diatom species were chosen because they are of similar size, and are both ingested and assimilated by harpacticoids (Scottolana canadensis, Cletocamptus deitersi, Microarthridion Littorali) (Decho unpubl.).

Labelling diatoms. Diatoms, in their log phase of growth, were labelled with $\mathrm{NaH}^{14} \mathrm{CO}_{3}$ (New England Nuclear, Boston, Massachusetts, $10 \mu \mathrm{g} \mathrm{MCi}^{-1}$; 60 $\mu \mathrm{Ci}^{-1}$ final conc.) for $2 \mathrm{~d}$. At this time unincorporated label and antibiotic were removed by multiple ( 6 to 7 ) centrifugation (6000 rpm for $10 \mathrm{~min}$ ), resuspending in $40 \mathrm{ml}$ sterile ASW. The final pellet was resuspended in $10 \mathrm{ml}$ sterile ASW to yield a concentrated diatom suspension.

Linear uptake of label was examined by subsampling 2 sets of triplicate $100 \mathrm{\mu l}$ aliquots over a time series $(1,2,4,6,8,12,24,48 \mathrm{~h})$ during incubations. One set was placed directly in scintillation vials containing $1.5 \mathrm{ml}$ Protosol (NE Nuclear), heated in darkness at ca $60^{\circ} \mathrm{C}$ for $4 \mathrm{~h}$, cooled and counted on a Beckman LS8000 Scintillation counter using $10 \mathrm{ml}$ Econofluor (NE Nuclear) as the scintillation cocktail.
Quenching was corrected for using the external-standards ratio method. A second set of triplicate samples were cleared of unincorporated label (by centrifugation) with the pellet placed in scintillation vials and counted. Dark incubated controls were used to account for non-photosynthetic incorporation of label.

To measure the specific activity of ${ }^{14} \mathrm{C}$-diatoms, triplicate subsamples $(100 \mu l)$ of diatoms were solubilized and counted by liquid scintillation counting (LSC). Diatom densities (cells $\mathrm{ml}^{-1}$ ) were measured in triplicate by haemocytometer. Therefore, the specific activity $\left(\mathrm{dpm} \mathrm{cell}^{-1}\right)$ could be measured. Specific activities of centrifuge-washed diatoms were measured at both the start and conclusion of $1 \mathrm{~h}$ feeding experiments using parallel samples to account for decreases in specific activity due to ${ }^{14} \mathrm{C}$-exudate loss during $1 \mathrm{~h}$ feeding experiments. Differences were analysed by ANOVA (SAS Institute Inc. 1982). The mean specific activity (from start and conclusion samples) was used later to calculate copepod ingestion rates.

Sediment preparation. Four separate treatments (Fig. 1) were constructed: 2 High-water treatments (HW-Tmt) and 2 Low-water treatments (LW-Tmt) using circular sediment microcosms $(3.4 \mathrm{~cm}$ dia). Sediment used in experiments was collected from the same site as the experimental animals and processed according to the methods of Chandler (1986). Each HW-Tmt contained $5 \mathrm{ml}$ of ASW (final volume) overlying the sediment layer. LW-Tmts contained no overlying seawater cover in order to simulate an exposed mudflat at lowtide.

Feeding experiment. For feeding experiments, harpacticoids were prestarved no longer than $15 \mathrm{~min}$ (maximum handling time) in order to reduce ingestion rate artifacts due to starvation effects (Hassett \& Landry 1983, Murtaugh 1984). Addition of food diatoms occurred in the following manner: for HW-Tmts, first, benthic diatoms (Amphora tenernima) were added gently and close to the sediment, then allowed to settle and adhere to the sediment surface; second, 30 adult copepods of a given species were added; and third, immediately after, the planktonic diatoms (Thalassiosira weissflogii) were added. This set-up allowed minimal resuspension of sediment diatoms and also allowed planktonic diatoms to remain in suspension. To one HW-Tmt (Fig. 1a) ${ }^{14} \mathrm{C}$-labelled planktonic diatoms and unlabelled sediment diatoms were added. ${ }^{14} \mathrm{C}$-label levels in the overlying seawater were measured in this Tmt at the start and conclusion of the feeding experiment to examine if a significant loss of label (due to settling of ${ }^{14} \mathrm{C}$-planktonic diatoms) occurred during this time. To a second HW-Tmt (Fig. 1b), unlabelled planktonic diatoms and ${ }^{14} \mathrm{C}$-labelled benthic-diatoms were added. ${ }^{14} \mathrm{C}$-label levels of overlying water were also measured at the beginning and 
HIGH-WATER TMT

Fig. 1. Arrangement of ${ }^{14} \mathrm{C}$ labelled diatoms in HighWater (HW) and Low-Water (LW) treatments used in feeding experiments (ASW = Instant Ocean Artificial Seawater)

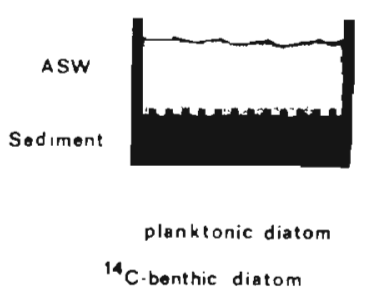

conclusion of the feeding experiment to ensure that benthic-diatoms were confined to the sediment and to examine if significant resuspension had occurred during the feeding experiments. To LW-Tmts (Fig. 1c \& d) a similar format was followed in the additions of diatoms. For each feeding experiment, 3 pre-measured diatom food concentrations were used and are designated as Low, Medium, and High. Approximately equal concentrations of ${ }^{14} \mathrm{C}$-labelled and unlabelled diatoms were added to LW-Tmts. Proportionally higher concentrations of planktonic diatoms were added to HW-Tmts to account for the dilution of the overlying water.

Harpacticoid feeding time was always $1 \mathrm{~h}$. This is less than the minimum gut-retention time as determined by azo-carmine appearance (Icely \& Nott 1985) in the fecal pellets of the 3 species fed under similar conditions (i.e. temperature and food concentrations) (Decho unpubl.). Therefore, loss of ingested label via fecal pellets could be assumed to be zero. Also, as a second control, fecal pellets, collected from copepods used in feeding experiments were examined by LSC for the presence of ${ }^{14} \mathrm{C}$ and compared to control fecal pellets (collected from copepods fed unlabelled diatoms). Ten fecal pellets were used for each sample. Samples were run in triplicate.

At the conclusion of the $1 \mathrm{~h}$ feeding period, individuals were removed from the sediment, washed in sterile ASW and transferred to scintillation vials using $200 \mu \mathrm{l}$ ASW, prepared, and counted by LSC. Seven individuals were used in each replicate, with 4 replicates per treatment.

Controls. In order to control for harpacticoid uptake of ${ }^{14} \mathrm{C}$-label not as a result of ingesting diatoms, adults of each species were added to sediment containing the ${ }^{14} \mathrm{C}$-labelled diatom filtrate $(0.8 \mu \mathrm{m}$ Gelman filter $)$. This filtrate was collected from ${ }^{14} \mathrm{C}$-labelled diatoms incubated in sterile ASW for $1 \mathrm{~h}$ (same time-length as feeding experiments). The diatom concentrations were of similar densities as those used in feeding experiments. The control copepods were incubated for $1 \mathrm{~h}$, then removed and washed, and counted by LSC. This will more precisely control for ${ }^{14} \mathrm{C}$-diatom exudates, and leaky diatom intracellular products which the
LOW-WATER TMT

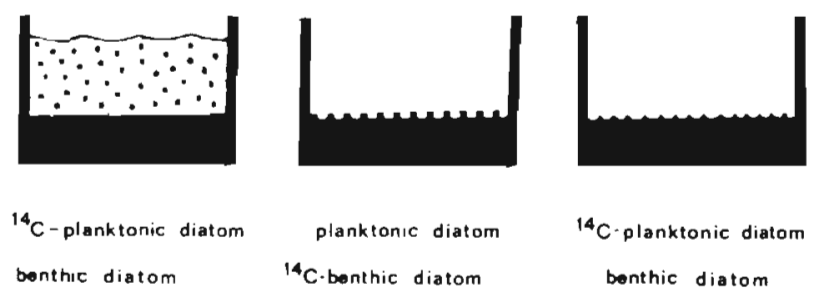

copepods are exposed to during feeding experiments than the standard $\mathrm{NaH}^{14} \mathrm{CO}_{3}$ in sterile $\mathrm{SW}$ controls (own obs.). Controls (dpm) were subtracted from Tmt level readings

Respiration of ${ }^{14} \mathrm{CO}_{2}$ during $1 \mathrm{~h}$ feeding experiments was measured in triplicate using separate $25 \mathrm{ml}$ flasks, according to a modification of Hobbie \& Crawford (1969). Each flask contained 7 individuals and was set up similarly to 1 of the 4 Tmts used in feeding experiments.

Data analysis. Ingestion rate data were analysed by 3-way ANOVA using General Linear Models (SAS, 1982). If a significant difference was indicated, Bonferroni's test was applied for comparison of means.

\section{RESULTS}

\section{Food concentrations}

Analysis of ${ }^{14} \mathrm{C}$-bicarbonate uptake by cells of both diatom species (Thalassiosira weissflogii, Amphora tenerrima) over a time series indicate linear uptake of label over the first $6 \mathrm{~h}$ of incubation. After $2 \mathrm{~d}$ incubation a near-homogeneous distribution of label among diatom cells was assumed. Dark incubated controls showed no significant uptake over a $48 \mathrm{~h}$ period. Specific activities of ${ }^{14} \mathrm{C}$-diatoms used in each of the feeding experiments are summarized in Table 1 and ranged from 0.4 to $3.4 \mathrm{dpm}$ (diatom cell) ${ }^{-1}$. Food concentrations of labelled and unlabelled diatom were similar at each HW and LW-Tmt food concentration.

Analysis of $\mathrm{HW}^{14} \mathrm{C}$ planktonic diatom Tmts (to determine if planktonic diatoms remained suspended in the water column during $1 \mathrm{~h}$ feeding experiments) indicated no significant $(\mathrm{P}>0.01)$ reduction in water column ${ }^{14} \mathrm{C}$-diatoms after $1 \mathrm{~h}$. Analysis of water aliquots from ${ }^{14} \mathrm{C}$-benthic diatom Tmts showed no significant label in the water column indicating no appreciable suspension of ${ }^{14} \mathrm{C}$-sediment diatoms during $1 \mathrm{~h}$ feeding experiments. Therefore it could be assumed that during $1 \mathrm{~h}$ feeding experiments, planktonic-diatoms remained suspended in the water column and benthic-diatoms remained associated with the sediment. 
Table 1. Mean ( $\pm \mathrm{SE}$ ) food concentrations of diatoms (cells $\mathrm{ml}^{-1}$ ) for each treatment (Tmt) used in feeding experiments for each food concentration. Specific activities (dpm cell ${ }^{-1}$ ) of diatoms in parentheses

\begin{tabular}{|c|c|c|c|c|c|}
\hline \multirow[t]{2}{*}{ Harpacticoid } & \multirow[t]{2}{*}{ Food conc. } & \multicolumn{2}{|c|}{ High-water Tmt } & \multicolumn{2}{|c|}{ Low-water Tmt } \\
\hline & & $\begin{array}{c}\text { Planktonic } \\
(T . \text { weissflogii) }\end{array}$ & $\begin{array}{c}\text { Benthic } \\
\text { (A. tenernima) }\end{array}$ & $\begin{array}{c}\text { Planktonic } \\
(T . \text { weissflogii) }\end{array}$ & $\begin{array}{c}\text { Benthic } \\
\text { (A. tenerrima) }\end{array}$ \\
\hline S. canadensis & $\begin{array}{l}\text { Low } \\
\text { Medium } \\
\text { High }\end{array}$ & $\begin{array}{r}44350 \pm 1198 \\
(1.8) \\
83950 \pm 1919 \\
(1.6) \\
161450 \pm 4032 \\
(1.4)\end{array}$ & $\begin{array}{r}33750 \pm 1220 \\
(0.44) \\
79200 \pm 1345 \\
(1.5) \\
148600 \pm 4460 \\
(1.0)\end{array}$ & $\begin{array}{r}27500 \pm 743 \\
(1.8) \\
52050 \pm 1190 \\
(1.6) \\
100100 \pm 2500 \\
(1.4)\end{array}$ & $\begin{array}{r}33750 \pm 1220 \\
(0.44) \\
79200 \pm 1345 \\
(1.5) \\
148600 \pm 4460 \\
(1.0)\end{array}$ \\
\hline C. deitersi & $\begin{array}{l}\text { Low } \\
\text { Medium } \\
\text { High }\end{array}$ & $\begin{array}{r}17680 \pm 645 \\
(1.7) \\
48240 \pm 1887 \\
(2.55) \\
127350 \pm 6758 \\
(2.2)\end{array}$ & $\begin{array}{r}10330 \pm 520 \\
(1.1) \\
49440 \pm 2070 \\
(1.6) \\
132300 \pm 4230 \\
(3.1)\end{array}$ & $\begin{array}{r}11000 \pm 400 \\
(1.7) \\
30000 \pm 1170 \\
(2.55) \\
79200 \pm 4190 \\
(2.2)\end{array}$ & $\begin{array}{r}10330 \pm 520 \\
(1.1) \\
49440 \pm 2070 \\
(1.6) \\
132300 \pm 4230 \\
(3.1)\end{array}$ \\
\hline M. littorale & $\begin{array}{l}\text { Low } \\
\text { Medium } \\
\text { High }\end{array}$ & $\begin{array}{r}52580 \pm 1800 \\
(2.2) \\
108064 \pm 2090 \\
(1.4) \\
155610 \pm 3483 \\
(1.05)\end{array}$ & $\begin{array}{r}29020 \pm 1350 \\
(3.1) \\
61600 \pm 2246 \\
(1.0) \\
88440 \pm 4685 \\
(2.6)\end{array}$ & $\begin{array}{r}32600 \pm 1116 \\
(2.2) \\
67000 \pm 1300 \\
(1.4) \\
96500 \pm 2160 \\
(1.05)\end{array}$ & $\begin{array}{r}29020 \pm 1350 \\
(3.1) \\
61600 \pm 2246 \\
(1.0) \\
88440 \pm 4685 \\
(2.6)\end{array}$ \\
\hline
\end{tabular}

Water contents of sediments from LW-Tmts ranged between 1.51 and $1.63 \mathrm{ml}$ equivalents of $\mathrm{dH}_{2} \mathrm{O} \mathrm{g}^{-1}$ dry sediment. These values are within the range of those observed at low-tide in the field habitat of the harpacticoids used in the experiments (own obs.).

\section{Feeding experiments}

Harpacticoid feeding experiments indicate that ingestion rates over the simulated parts of a tidal cycle vary significantly, depending on the harpacticoid species and the type of food (planktonic or benthic) ingested.

Scottolana canadensis showed greatest variation in diatom ingestion rates (Fig. 2) with regard to both ambient water level (HW vs LW) and diatom type (benthic vs planktonic). Highest total ingestion rates ( $P<0.001$ by Bonferroni test) occurred during HW conditions with very low ingestion rates during LW conditions, over all 3 food concentrations. Ingestion rate increased with increasing food concentration (Fig. 2). Also, during HW conditions, 60 to $88 \%$ of the diatoms consumed were planktonic (Thalassiosira weissflogii), indicating a $2 \times$ greater rate than the consumption rate of benthic-diatoms (Amphora tenerrima). During LW conditions however, ingestion of planktonic diatoms and benthic diatoms did not differ significantly $(\mathrm{P}>0.05)$.

Cletocamptus deitersi exhibited relatively similar ingestion rates at both HW and LW conditions, except low-food concentrations (Fig. 2). Here ingestion rates were significantly $(\mathrm{P}<0.05)$ greater during $\mathrm{HW}$ conditions.

Microarthridion littorale showed similar trends for total consumption of diatoms with slightly higher mean rates during LW conditions. However, during HW conditions, planktonic diatoms were consumed at much higher rates $(\mathrm{P}>0.001)$ than benthic diatoms (Fig. 2). This pattern was present over all 3 food concentrations. Ingestion rates of both planktonic and benthic diatoms increased with increasing food concentration.

Respiration of ${ }^{14} \mathrm{CO}_{2}$ varied in magnitude depending on the species and quantity of food consumed. Approximately 19 to $28 \%$ of the ingested ${ }^{14} \mathrm{C}$-diatom label was respired by the 3 harpacticoid species. Values at each Tmt food-concentration are given in Table 2 .

Analysis of fecal pellets collected from copepods used in feeding experiments indicated no appreciable amounts of ${ }^{14} \mathrm{C}$ above control levels could be detected for any of the 3 harpacticoid species. This indicates there was no appreciable loss or recycling of ${ }^{14} \mathrm{C}$-label via fecal pellets during the $1 \mathrm{~h}$ feeding experiments.

\section{DISCUSSION}

Significant variability in ingestion rates for meiobenthic copepods results from (1) the presence or absence of water-cover (HW vs LW), and/or (2) the type of diatom (planktonic-suspended or benthic) ingested. 


\section{S. canadensis}
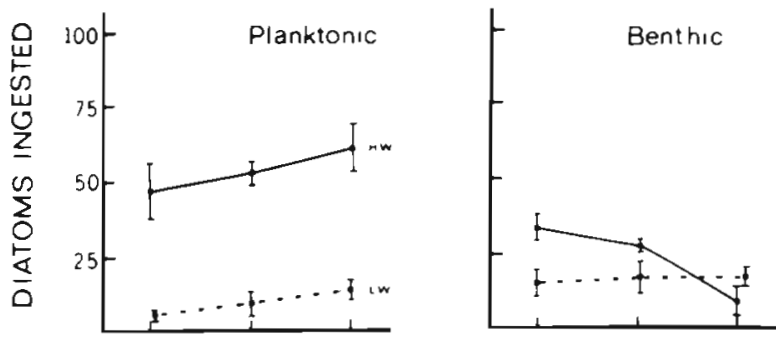

\section{C. deitersi}
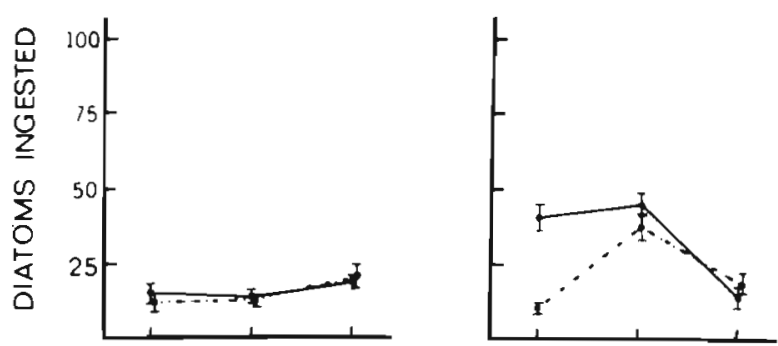

\section{Iittorale}
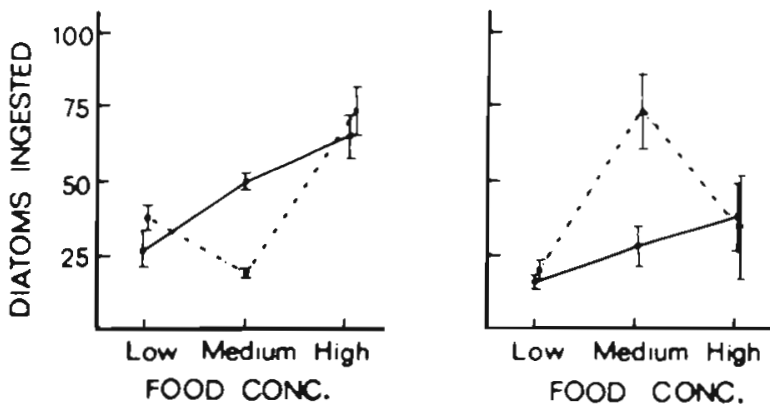

Fig. 2. Ingestion rates (no. diatoms ingested copepod ${ }^{-1} \mathrm{~h}^{-1}$ ) of planktonic (Thallassiosisa weissflogii) and benthic (Amphora tenerrima) diatoms by 3 harpacticoids during HW and LW conditions. Vertical bars denote $\mathrm{SE}_{\bar{x}}$
Two of the 3 harpacticoid species examined showed significant differences in ingestion rates of diatoms with regard to these parameters.

During High-water (HW), Scottolana canadensis ingested more diatoms than during low-water (LW) over all food concentrations. This increased feeding rate was primarily due to the increased consumption of planktonic diatoms (Fig. 2) at HW. As food concentration increased, a greater percentage of ingested food was planktonic. Ingestion of benthic (sediment) diatoms remained relatively constant $(P>0.05)$ between HW and LW.

Laboratory and field observations of Scottolana canadensis at HW and LW indicate it to be a semisessile burrow-dweller. During HW conditions, $S$. canadensis constructs a semi-permanent burrow in which it resides (although individuals occasionally enter the water column). By use of its appendages, water and particulate matter from the overlying water column are drawn into the burrow (G. T. Chandler pers. comm.). The majority of this material consists of suspended plankton and detritus, with also some sediment particles (and benthic diatoms) in proximity to the burrow opening. The material is concentrated into a bolus (Chandler pers. comm.), with some of the bolus being ingested, and the remainder being discarded out of the opposite end of the burrow. The mechanics of particle selection are unknown. Both short-range (i.e. tactile) and long-range chemoreception may contribute as in some planktonic copepods (Paffenhöfer \& Van Sant 1985). During LW conditions, $S$. canadensis is occasionally seen moving atop the sediment surface, but most often resides within its burrow. Feeding at this time is reduced to that material already within its burrow or in immediate proximity to its burrow, and feeding rates are significantly reduced.

Predelection of Scottolana canadensis toward planktonic food sources is characteristic of both adults and nauplii. Adults grow best in culture on a variety of

Table $2 .{ }^{14} \mathrm{C}$-label respired ( $\mathrm{dpm}$ copepod ${ }^{-1} \mathrm{~h}^{-1}$ ) during $1 \mathrm{~h}$ feeding experiments. Values expressed as mean $\pm \mathrm{SE}$ (percentage of ingested label respired in parentheses!

\begin{tabular}{|c|c|c|c|c|c|}
\hline \multirow[t]{2}{*}{ Harpacticoid } & \multirow[t]{2}{*}{ Food conc. } & \multicolumn{2}{|c|}{ High-water Tmt } & \multicolumn{2}{|c|}{ Low-water Tmt } \\
\hline & & Planktonic diatom & Benthic diatom & Planktonic diatom & Benthic diatom \\
\hline \multirow[t]{3}{*}{ S. canadensis } & Low & $21.0 \pm 3.4$ & $4.2 \pm 2.4$ & $1.2 \pm 0.4$ & $1.1 \pm 0.3$ (19) \\
\hline & Medium & $16.0 \pm 2.1$ & $10.0 \pm 2.4$ & $3.5 \pm 0.6 \quad(20)$ & $6.3 \pm 0.9(28)$ \\
\hline & High & $18.0 \pm 4.0$ & $2.4 \pm 1.1$ & $6.0 \pm 1.3(28)$ & $4.5 \pm 1.1$ \\
\hline \multirow[t]{3}{*}{ C. deitersi } & Low & $6.0 \pm 1.1 \quad(22)$ & $9.0 \pm 2.3(24)$ & $5.0 \pm 0.7$ & $2.4 \pm 0.4 \quad(27)$ \\
\hline & Medium & $7.5 \pm 1.6$ & $19.0 \pm 1.6(26)$ & $7.6 \pm 0.3$ & $12.7 \pm 1.7$ \\
\hline & High & $7.9 \pm 0.6(19)$ & $10.0 \pm 0.4$ & $13.2 \pm 0.7$ & $15.8 \pm 2.7$ \\
\hline \multirow[t]{3}{*}{ M. Littorale } & Low & $11.3 \pm 2.0$ & $10.8 \pm 1.6$ & $18.8 \pm 1.1$ & $16.0 \pm 2.6$ \\
\hline & Medium & $17.3 \pm 2.6 \quad(25)$ & $7.4 \pm 0.5$ & $5.1 \pm 0.7$ & $19.9 \pm 2.7$ \\
\hline & High & $13.0 \pm 2.1$ & $22.1 \pm 1.9$ & $18.6 \pm 2.6$ & $20.0 \pm 3.3(26)$ \\
\hline
\end{tabular}


planktonic diatoms (Harris 1977, Lonsdale \& Levinton 1985. Chandler 1986) and can often be collected at night from the water column in plankton tows ( $\mathrm{J}$. Howze pers. comm.). Nauplii are pelagic (Lonsdale \& Levinton 1985) and obligate planktivores (Harris 1977).

Diatom ingestion rates of Cletocamptus deitersi were slightly higher during HW conditions (at low and medium food concentrations), but more benthic diatoms were ingested regardless of water level. $C$. deitersi continuously crawls over the sediment surface and/or burrows throughout the sediment with intermittant periods of swimming through the water column. Movement is quite vigorous on the sediment during LW conditions. Swimming at $\mathrm{HW}$ can increase its foraging ability, especially at low food concentrations. This harpacticoid grows best in culture on a mixture of both planktonic diatoms and sediment diatoms (Chandler 1986).

Microarthridion littorale ingests similar amounts of total food between HW and LW conditions. Apparently it does so by shifting its feeding mode. During HW, it tends to feed on planktonic diatoms by spending a large portion of its time in the water column, first swimming upward, then 'dive-bombing' to the sediment surface (Chandler pers. comm.). M. littorale is easily suspended during HW and does not readily return to the sediment once suspended (Palmer 1984). At LW it feeds on either benthic diatoms or planktonic diatoms. During this time it actively plows across the sediment surface, apparently foraging. Its total ingestion rate increases slightly during LW. The increased consumption of benthic diatoms (and decrease in planktonic diatoms) during LW conditions is most pronounced at medium food concentrations. The reason(s) for this pattern are unclear. This copepod can be cultured on either planktonic diatoms (Chandler 1986) or benthic diatoms (Palmer \& Coull 1980).

Respiration values of ${ }^{14} \mathrm{CO}_{2}$ (Table 2) do not appear to reflect the relative activities (i.e. movements) of the harpacticoids during feeding but instead reflect only the amounts of ${ }^{14} \mathrm{C}$-labelled food ingested.

The ability of a meiobenthic animal to feed at HW and LW may potentially affect its distribution in the field. Mesoscale (meters) distributional variations of salt marsh meiobenthos have been documented by Phillips \& Fleeger (1985). Distributional changes in species composition have also been shown to occur over a vertical tidal gradient and are well established in some areas (Coull et al. 1979, Fleeger 1985).

Scottolana canadensis feeds at considerably higher rates during HW (under laboratory conditions). Field distributions of $S$. canadensis in Louisiana marshes reveal that it is associated with areas and times of the year when water cover predominates (HW conditions) for extended periods (Phillips \& Fleeger 1985). Here, it is commonly found in intertidal marsh ponds (Chandler \& Fleeger 1983, Phillips \& Fleeger 1985) and subtidal areas (Fleeger et al. 1983). High abundances in intertidal ponds tend to occur during late summer and fall, when predominant south winds override lunar tidal fluctuations, and the marsh remains at HW conditions for many weeks at a time (Whipple et al. 1981). During spring, when north winds predominate and the marsh is kept at LW conditions for extended periods, $S$. canadensis is typically found at low abundances intertidally (Phillips \& Fleeger 1985) with higher abundances subtidally (own obs.). S. canadensis has a wide geographical range (Coull 1972) and is most commonly found in shallow subtidal and low-intertidal brackishwater areas (Coull et al. 1979, Phillips \& Fleeger 1985) where water cover and plankton prevail.

Field distribution of Cletocamptus deitersi in Louisiana extends from subtidal to high intertidal. Its ability to ingest food diatoms under laboratory conditions indicates that it can feed equally well under both subtidal (HW) and high-intertidal (mainly LW) conditions.

The distribution of Microarthridion littorale extends from subtidal to high intertidal in South Carolina marshes (Coull et al. 1979) comprising 2 definable subpopulations differing in size and life history patterns (Palmer 1980). Its range of distribution from subtidal to high marsh documents its ability to exist under prolonged HW and/or LW conditions. In Louisiana, however, the range of $M$. littorale is confined to the low intertidal and primarily subtidal regions of marshes (Fleeger 1985). Reasons for this somewhat restricted distribution have been postulated by Fleeger (1985) but are still unknown. M. Littorale can consume a relatively constant amount of diatoms at HW vs LW conditions by apparently shifting its feeding mode from pelagic to benthic. However, field verification of such shifts (observed in laboratory experiments) would be especially important because other factors may play a role. Predation, time of day (day vs dusk vs night) (Bell et al. 1984), and hydrodynamics during HW (Eckman 1983, Jumars \& Nowell 1984) and associated tidal resuspension (Palmer \& Brandt 1981, Fleeger et al. 1984) can influence the pelagic or epibenthic behavior of some meiofauna (Palmer 1984) ultimately restricting them to the sediment. Variable food supply (Bulthuis et al. 1984, Kirchman et al. 1984, Webb \& Marcotte 1984, Laanbroek \& Vernplanke 1986) may also influence the behavior of meiobenthic species (Chandler pers. comm.). In my studies, keeping these other factors constant, ambient water-cover alone could significantly influence the ability of some meiobenthos to ingest food.

Meiobenthos are not confined to the sediment (Bell 
\& Sherman 1980, Hagerman \& Rieger 1981, Bell et al. 1984, Fleeger et al. 1984, Jumars \& Nowell 1984, Palmer 1984, and others). Consumption of, and persistence on, planktonic food in the lab indicates for some meiobenthos a potentially close coupling with the overlying plankton. More precise estimation of meiobenthic consumption effects on benthic and pelagic microbial communities in the field, and of the overall role of meiobenthos in energy flow requires species-specific grazing-rate measurements (in conjunction with species abundance and production estimates) where logistically possible. Energy flow through the meiobenthos may be underestimated (Kuipers et al. 1981, Strayer \& Likens 1986); field studies measuring meiobenthic grazing rates have been few (Admiraal et al. 1983, Montagna 1984, Strayer \& Likens 1986) and have been largely been confined to examining major taxa. The importance of these rate measurements in the field cannot be overstated with regard to quantifying the role of the meiobenthos as consumers and producers.

Finally, the ability of a meiobenthic species to feed during $\mathrm{HW}$ and LW can potentially affect energy-flow estimates of meiobenthos, depending on the portion of a tidal cycle measured. Also, the field distribution of a meiobenthos species, with respect to the total amount of time it is covered with water, should be in accordance with its ability to feed under those conditions if it is to maximize its energy intake. Field verification of these rate differences is required, as other factors such as food availability, predation, and hydrodynamic effects - can either compound or reduce differences observed in the laboratory.

Acknowledgements. I thank Dr. Michael J. Sullivan, Mississippi State University, for identification of benthic diatoms; Dr. John W. Fleeger for critical help on earlier drafts of the manuscript; and G. Thomas Chandler for invaluable discussion on the behavioral aspects of the copepods used. I also thank the staff of the Louisiana Universities Marine Consortium (LUMCON) for use of their facilities and assistance in field collections. This research was supported by the Oceanography Section, National Science Foundation, Doctoral Dissertation Improvement Grant (OCE-8313109), and a Sigma Xi Grants in Aid to A. W. Decho.

\section{LITERATURE CITED}

Admiraal, W., Bouwman, L. A., Hockstra, L., Romeyn, K. (1983). Qualitative and quantitative interactions between microphytobenthos and herbivorous meiofauna on a brackish intertidal mudflat. Int. Revue ges. Hydrobiol. 68 : 175-191

Bell, S. S. (1980). Meiofauna-macrofauna interactions in a high salt marsh habitat. Ecol. Monogr. 50: 487-505

Bell, S. S., Sherman, K. S. (1980). Tidal resuspension as a mechanism for meiofauna dispersal. Mar. Ecol. Prog. Ser. 3: $245-249$

Bell, S. S., Walters, K., Kern, J. C. (1984). Meiofauna from seagrass habitats: a review and prospectus for future research. Estuaries 7: 331-338

Bodiou, J. Y., Villiers, L. (1978). La predation de la meiofaune par les formes juveniles de Deltentosteus quadrimaculatus (Teleostei, Gobiidae). Vie Milieu Ser. AB 28-29, 1978-1979: 143-156

Bulthuis, D. A., Brand, G. W., Mobley, M. C. (1984). Suspended sediments and nutrients in water ebbing from seagrass-covered and denunded tidal mudflats in a southern Australian embayment. Aquat. Bot. 20: 257-266

Chandler, G. T. (1986). High-density culture of meiobenthic harpacticoid copepods within a muddy sediment substrate. Can. J. Fish. Aquat. Sci. 43: 53-59

Chandler, G. T., Fleeger, J. W. (1983). Meiofaunal colonization of azoic sediments in Louisiana: Mechanisms of dispersal. J. exp. mar. Biol. Ecol. 69: 175-188

Coull, B. C. (1972). Scottolana canadensis (Copepoda, Harpacticoida) redescribed from the United States east coast. Crustaceana 22: 209-214

Coull, B. C., Bell, S. S., Savory, A. M., Dudley, B. W. (1979). Zonation of meiobenthic copepods in a southeastern United States salt marsh. Estuar. coast. mar. Sci. 9: $181-188$

Eckman, J. E. (1983). Hydrodynamic processes affecting benthic recruitment. Limnol. Oceanogr. 28: 241-257

Fleeger, J. W. (1980). Community structure of an estuarine meiobenthic copepod assemblage. Estuar. coast. mar. Sci. 10: $107-117$

Fleeger, J. W. (1985). Meiofaunal densities and copepod species composition in a Louisiana, U.S.A., estuary. Trans. Am. microsc. Soc. 104: 321-332

Fleeger, J. W., Sikora, W. B., Sikora, J. P. (1983). Spatial and long-term temporal variation of meiobenthic-hyperbenthic copepods in Lake Ponchartrain, Louisiana. Estuar. coast. Shelf Sci. 16: 441-453

Fleeger, J. W., Chandler, G. T., Fitzhugh, G. R., Phillips, F. E. (1984). The effects of tidal currents on meiofauna densities in vegetated salt marsh sediments. Mar. Ecol. Prog. Ser 19: $49-53$

Guillard, R. R., Ryther, J. H. (1962). Studies of marine planktonic diatoms. I. Cyclotella nana Hustedt, and Detonula confervacea (Cleve) Gran. Can. J. Microbiol. 8: 229-239

Hagerman, G. M., Rieger, R. M. (1981). Dispersal of benthic meiofauna by wave and current action in Bogue Sound, North Carolina, U.S.A. P.S.Z.N. Mar. Ecol. 2: 245-270

Harris, R. P. (1977). Some aspects of the biology of the harpacticoid copepod, Scottolana canadensis (Willey), maintained in laboratory culture. Chesapeake Sci. 18: 245-252

Hobbie, J. E., Crawford, C. C. (1969). Respiration corrections for bacterial uptake of dissolved organic compounds in natural waters. Limnol. Oceanogr. 14: 528-532

Icely, J. D., Nott, J. A. (1985). Feeding and digestion in Corophium volutator (Crustaceana: Amphipoda). Mar. Biol. 89: 183-195

Jumars, P. A., Nowell, A. R. M. (1984). Fluid and sediment dynamic effects on marine benthic community structure. Am. Zool. 24: 45-55

Kirchman, D., Peterson, D., Juers, D. (1984). Bacterial growth and tidal variations in bacterial abundance in the Great Sippewissett Salt Marsh. Mar. Ecol. Prog. Ser. 19: 247-259

Kuipers, B. R., de Wilde, P. A. W. J., Creutzberg (1981). Energy flow in a tidal flat ecosystem. Mar. Ecol. Prog. Ser. 5: $215-221$

Laanbroek, H. J., Verplanke, J. C. (1986). Tidal variations in bacterial biomass, productivity and oxygen uptake rates in a shallow channel in the Oosterschelde basin. The Netherlands. Mar. Ecol. Prog. Ser. 29: 1-5 
Lonsdale, D. J., Levinton, J. S. (1985). Latitudinal differentiation in copepod growth: an adaptation to temperature. Ecology 66: 1397-1407

Montagna, P. A. (1984). In situ measurement of meiobenthic grazing rates on sediment bacteria and edaphic diatoms. Mar. Ecol. Prog. Ser. 18: 119-130

Paffenhöfer, G., Van Sant, K. B. (1985). The feeding response of a marine planktonic copepod to quantity and quality of particles. Mar. Ecol. Prog. Ser. 27: 55-65

Palmer, M. A. (1980). Variations in life history patterns between intertidal and subtidal populations of the meiobenthic copepod Microarthridion littorale. Mar. Biol. 60: 159-165

Palmer, M. A. (1984). Invertebrate drift: behavioral experiments with intertidal meiobenthos. Mar. Behav. Physiol. 10: $235-253$

Palmer, M. A., Brandt, R. R. (1981). Tidal variation in sediment densities of marine benthic copepods. Mar. Ecol. Prog. Ser. 4: 207-212

Palmer, M. A., Coull, B. C. (1980). The prediction of developmental rate and the effect of temperature for the meioben- thic copepod, Microarthridion Littorale (Poppe). J. exp. mar. Biol. Ecol. 48: 73-83

Phillips, F. E., Fleeger, J. W. (1985). Meiofauna meso-scale variability in two estuarine habitats. Estuar. coast. Shelf Sci. 21: 745-756

Price, H. J., Paffenhöfer, G. (1984). Effects of feeding experience in the copepod Eucalanus pileatus: a cinematographic study. Mar. Biol. 84: 35-40

SAS Institute, Inc. (1982). SAS User's Guide: Statistics. SAS Institute, Inc. Cary, North Carolina

Strayer, D., Likens, G. E. (1986). An energy budget for the zoobenthos of Mirror Lake, New Hampshire. Ecology 67 303-313

Webb, D. G., Marcotte, B. M. (1984). Resource predictability and reproductive strategy in Tisbe cucumariae Humes (Copepoda: Harpacticoida). J. exp. mar. Biol. Ecol. 77: $1-10$

Whipple, S. A., Fleeger, J. W., Cook, L. L. (1981). Field manipulations of tidal flushing, light exposure and natant macrofauna on edaphic chlorophyll $a$ in a Louisiana salt marsh. Estuar. coast. Shelf Sci. 13: 637-643

This article was presented by Professor K. R. Tenore; it was accepted for printing on August 14, 1986 